\title{
Side Light: Locus Iste. A Meditation
}

Locus iste a Deo factus est. Inaestimabile sacramentum irreprehensibilis est.
This place was made by God,

a priceless sacrament;

it is without reproach.

In my teens I was part of a small chamber choir. I have fond recollections of Wednesday evenings in the empty church, with its Roman and gothic architecture, in which we practised some of the loveliest pieces of choral music that I have had the chance to sing. Among the pieces I recall us rehearsing is Anton Bruckner's well-known gradual Locus iste ('This place', WAB23). Bruckner (1824-1896) composed the motet for the dedication of the new cathedral's Votivkapelle in the Austrian city of Linz in September 1869. ${ }^{1}$ The composition is based on the biblical narrative of Jacob, in which Jacob lies down to sleep at Bethel and has a dream, as a consequence of which he then identifies the place where he has slept as sacred ground. In Genesis 28,17 Jacob exclaims: "How awesome is this place! This is none other than the house of God, and this is the gate of heaven". Bruckner uses a more elaborate textual form for his motet, incorporating Jewish pseudepigraphal textual material, and the form which he uses is also known as the Latin gradual for the dedication of a church in the Roman Catholic liturgical tradition. Bruckner thus connects the ideas that 'this place was made by God' with a church building that, through its consecration, was to become a priceless sacrament. Ever since I became acquainted with the piece, I have been impressed by this very fine musical miniature, and the way in which Bruckner has used harmonic and melodic movements to set to music that particular moment when Jacob, to his surprise, recognizes a particular, ordinary place as sacred. This place is 'a Deo factus': made by God. The sacred is at the same time both identified by Jacob and God-given.

The surprise experienced by Jacob seems crucial to me. It suggests that blissful occurrences that we don't see coming, whether they be things we learn,

1 Alan Howie, "Bruckner and The Motet", in The Cambridge Companion to Bruckner, Cambridge Companions to Music, ed. J. Williamson (Cambridge: Cambridge University Press, 2004). DOI: 10.1017/CCOL9780521804042.006.

(C) MIRELLA KLOMP, 2020 | DOI:10.1163/9789004442948_007

This is an open access chapter distributed under the terms of the CC BY-NC 4.o license 
actions, unexpected results, or the amazing sensation that things have developed differently than we had expected, are a part of the process by which we identify the sacred. I tend to think that surprise is somehow always a part of it: the experience of the sacred is never entirely the result of a process that we have initiated and completed, but has aspects that seem to come to us from an 'outside' source, and which we do not fully control. This surprise may not always be a pleasant surprise however. It is also possible that the sacred might be found in negative things that occur to us (the story of the passion and crucifixion is the best example of this), in obnoxious things, uncomfortable experiences and in the hideous results of what we produce, know, or believe.

A Sunday evening in September 2012. The church choir that I am part of has sung Evensong in the Oude Kerk ('Old Church') in Amsterdam city centre, in the heart of what is known as the 'Red Light District'. We have celebrated the feast of the dedication of the church, that was consecrated in 1306, by singing Psalms and hymns and Bruckner's motet Locus iste. After evensong, I leave the church through the tower entrance to arrive at the square where window brothels, bars, cannabis and tattoo shops, and residential houses surround the church building. It is impossible not to catch a glimpse of the big breasts of the scarcely clothed sex workers who sit behind their windows. Every week, a local worshipping community gathers in this place to seek the face of God, at a time when people just outside of the building are watching soccer matches on big screens in bars, getting drunk whilst loudly slurring their chants of support or, at a distance of less than 20 metres from the church, having paid-for sex. Traces of God can occur in the silliest, the most surprising and the most vulnerable places: not only in a church building or in worship, but also - maybe even more so - between the sheets where sex is an economic product sold and bought instead of a practice of love. I hum while looking for my bike, and go home. Irreprehensibilis est. Even this place is an excellent place for God to become present.

Jacob, in Genesis 28 , is on his way from Beersheba to Harran. He has left his own land after a conflict with his older brother Esau, whose birth right and blessing he has stolen, and now he is travelling in a foreign land as a stranger and as a guest. Having gotten himself into trouble he is now a man on the run. I use his journey as a metaphor for the times in our lives in which we are, voluntarily or involuntarily, moving away from a place where we are no longer 
able to stay. A time when we are moving away from people with whom we can no longer live, work or even be together in the same space. A time when brothers and sisters do not manage to live up to the good and pleasant situation in which brothers and sisters dwell together in unity (Ps. 133:1). A time when we find ourselves in serious conflict. But it can also serve as an image for situations in which for some reason our professional positions have become untenable, for times of war, or for times when we leave existing structures behind (friends or family members, particular religious practices or images of God) in order to transition into a new phase. There are many different reasons for people to leave a place or flee from a situation, to go on a journey, or because of which they find themselves running into a foreign land.

Such journies come with uncertainties that make us feel vulnerable, and in those uncertainties, we may hang on to the things we hold particularly dear, just like Jacob does. When he reaches a certain place, he decides to spend the night there, and takes one of the regular, ordinary stones that he finds there, puts it under his head, and lays down to sleep. He then has a dream in which he sees a stairway which is rooted on the earth but whose upper end reaches up into heaven, with angels of God ascending and descending upon it. It seems to me that the angels feature in the dream in order to point towards Jacob's religious disposition: on his journey through a strange land, he is holding onto God. In the dream, our attention and the attention of Jacob is drawn to the upper end of the stairway. Apparently, Jacob has clear expectations of the place in which God dwells. But our attention is immediately steered right back down to the earth: Jacob does not find God upstairs but, unexpectedly, downstairs, right beside him. When we search for God, we may find God in an unexpected place. When Jacob wakes up, he recognizes the very place where he slept as a place where God dwells and, in astonishment, identifies it as the house of God: Bethel. The ordinary stone that he had used as a pillow becomes, at the same time, a sacrament: it is transformed into a sign to others of God's encounter with him.

Bruckner's composition employs stark musical imagery. The motion in the first section of his motet beautifully reflects the traffic of the angels on the stairway - descending on 'Locus iste', leaping sky-high at (the second) 'a Deo factus est', and gracefully ascending upwards as the choir sings 'inaestimabile sacramentum'. The same harmonic movement is then heightened further by a combination of transposition, an enhanced dynamic and the cumulative effect of repetition. Every time I hear or sing the piece, I am struck by its sense 
of forward motion. It is as if the sacred is never found straight away, never without some kind of intervening time or space, but only after movement, whether that movement be turbulent or inspiring in nature. In Genesis, Jacob is brought to a state of amazement and awe only after the elapse of a period of time in which angels ascend and descend upon the stairway. Bruckner's composition seems to suggest a rather orderly flow of angelic traffic, but this writing may well have been a deliberate attempt to suggest a feeling of rest and order: a few months after the first performance of the motet, the First Vatican Council was convoked as a response to the turmoil of a world in which Christian belief and the church as an institution had difficulties finding a place. In our own lives too, a transitional journey can sometimes be quite chaotic, and can also take some time. Those who have at some point been in such a situation may recognize the feeling that it seemed to take forever, or to lead nowhere: such a journey can sometimes consist of huge struggles. Anyone who has felt lonely or godforsaken for some reason, has been in serious conflicts or who, in whatever way, has gone through the darkness of death, may be familiar with the annoyance that certain phases simply last too long. Bruckner's threefold repetition of the words 'irreprehensibilis est' in the middle section of the motet is set as a stepwise chromatic descent, which is beautiful, but which almost feels too easy for me. When, after a journey through strange land, you find God in an unexpected place, then that may also come with negative experiences, with struggle, anger and frustration. Amazement and awe are wonderful, but one might also feel the need to throw some dishes.

The motet ends with a low final chord. Jacob identifies the strange soil, the foreign land through which he travels, where he is not at home and is uncertain of his safety, as the gate of heaven. This is a complete surprise: it is precisely when he is on the run, in the greatest misery which he has caused himself, that God meets Jacob. And Jacob recognizes and meets God. It might be precisely in the greatest distress, the deepest agony, the greatest dispute, that God encounters us and we encounter God.

When we undertake new quests for God in our own time and situation, we are travellers on journeys into strange lands. Our processes of sacred meaningmaking are not always neat and smooth: for many people the sacred no longer grows on trees, but is rather something to be recognised, discovered, and also negotiated. I like to interpret the narrative of Jacob at Bethel as a narrative which opens up the possibility that God appears not only in locations that we like or appreciate, but also in locations where we least expect it or places that 
we find dreadful. If you think that church is stuffy and "high church tradition" utterly boring, do not be surprised that God may live even in bread and wine. If you think of the church building as the preeminent place in which to encounter God, do not be surprised that God shows up to meet people in the streets. If you feel that the passion should be celebrated solemnly, do not be surprised that God casually pops up at a glitzy event. If you think of God as a being too sacred to engage with the mundane, do not be surprised to find God sitting next to people on the couch as they watch a dazzling passion show with their feet on the coffee table and eat cocktail nuts. God can be found in silly and surprising locations, and might even prefer to appear in broken places, places of conflict, of opposing interests, and of controversy and dispute. 